\title{
Colistin Sulphomethate Sodium Administration in the Presence of Severe Renal Failure and During Haemodialysis and Peritoneal Dialysis
}

\author{
J. R. CURTIS,* M.B., B.S., M.R.C.P. ; J. B. EASTWOOD, † M.B., B.S., M.R.C.P., D.OBST.R.C.o.G.
}

Brit. med.f., 1968, 1, 484-485

Colistin sulphomethate sodium is excreted largely via the kidneys (McMillan, Price, MacLaren, and Scott, 1962 ; Colley and Frankel, 1963). It was to be expected, therefore, that prolonged elevation of blood levels of the drug would occur in the presence of renal failure.

The present study was carried out to determine what modification in the dosage of colistin sulphomethate sodium was advisable in patients with severe renal failure, and what, if any, effect was produced by haemodialysis and peritoneal dialysis on blood levels of the drug.

The purpose of the study was carefully explained to all patients and their consent obtained before administering the drug.

We were aware of reports of nephrotoxicity due to colistin sulphate, but we consider this finding irrelevant to our situation, since all the patients had terminal and irreversible renal failure and all but one were on either intermittent haemodialysis or peritoneal dialysis awaiting renal transplantation.

One of the major problems of intermittent haemodialysis is infection of the arteriovenous shunt site, which so often leads to loss of the site. The significance of loss of a shunt site is of obvious importance and its significance does not escape the patient. Clearly, any information which might enable one to cure such an infection would be valuable. Our purpose was to determine a suitable and safe dosage schedule for colistin sulphomethate sodium in patients who are on intermittent haemodialysis or peritoneal dialysis. The importance of colistin sulphomethate sodium in peritoneal dialysis is that it may be the antibiotic of choice to treat pseudomonal peritoneal infections.

\section{Methods}

Colistin sulphomethate sodium was assayed by the plate technique with Bordetella bronchiseptica ATCC 4617 as test organism. This technique is sensitive to at least $1 \mu \mathrm{g} . / \mathrm{ml}$.

Colistin sulphomethate sodium, $3 \mathrm{mg} . / \mathrm{kg}$. body weight, was given in $20 \mathrm{ml}$. of $0.9 \%$ saline intravenously over five minutes to four patients with severe renal failure at a time when they were not being dialysed. Venous blood samples were taken at varying intervals after administration of the drug.

Three of these patients were undergoing twice-weekly taemodialysis, and a similar dose of colistin sulphomethate sodium was given to them on another occasion at the beginning of a dialysis. Arterial blood samples were taken before, during, and at the end of dialysis. Modified two-layer Kiil dialysers were used with cuprophane membrane (PT150). A single-pass warm dialysis $\left(37^{\circ}\right.$ C.) system was employed, and dialysis was carried out for periods varying from 11 to 16 hours.

Three other patients with severe renal failure were given colistin sulphomethate sodium 2 to $3 \mathrm{mg} . / \mathrm{kg}$. body weight intravenously while undergoing peritoneal dialysis. Venous

\footnotetext{
- Lecturer In Medicine, Charing Cross Hospital Medical School, Fulham Hospital, London $\$ 6$.

+ Medical Registrar, Fulham Hospital, London W.6.
}

blood samples were taken at varying intervals after administration of the drug together with aliquots from the peritoneal dialysis fluid. Commercially available peritoneal dialysis solutions (Dialaflex) and 30-minute equilibration periods with 2-litre exchanges were employed.

All plasma and peritoneal dialysate samples were stored at $-15^{\circ}$ C. until assayed.

\section{Results}

The endogenous creatinine clearances in five of the seven patients studied were less than $5 \mathrm{ml} . / \mathrm{min}$., with plasms creatinine levels ranging from 14.6 to $19.2 \mathrm{mg} . / 100 \mathrm{ml}$. One of the remaining two patients was virtually anuric and had a plasma creatinine level of $20 \mathrm{mg} . / 100 \mathrm{ml}$., while the other had an endogenous creatinine clearance of $8 \mathrm{ml} . / \mathrm{min}$. and a plasms creatinine level of $14.6 \mathrm{mg} . / 100 \mathrm{ml}$.

The diagnoses and renal function of these patients are shown in Table I. The blood urca and creatinine levels are those present when the patients were first seen and before treatment was instituted.

\begin{tabular}{|c|c|c|c|c|c|}
\hline \multirow{2}{*}{$\begin{array}{l}\text { Case } \\
\text { No. }\end{array}$} & \multirow{2}{*}{$\begin{array}{c}\text { Sex and } \\
\text { Age }\end{array}$} & \multirow{2}{*}{ Diagnoses } & $\begin{array}{c}\text { Blood } \\
\text { Urea }\end{array}$ & P. Cr. & \multirow{2}{*}{ 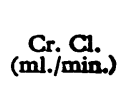 } \\
\hline & & & \multicolumn{2}{|c|}{$\mathrm{Mg} . / 100 \mathrm{ml}}$. & \\
\hline $\begin{array}{l}1 \\
2 \\
3 \\
4 \\
5 \\
6 \\
7\end{array}$ & $\begin{array}{l}\text { F. } 38 \\
\text { M. } 36 \\
\text { M. } 46 \\
\text { F. } 34 \\
\text { F. } \\
\text { M. } 38 \\
\text { P. } 28\end{array}$ & $\begin{array}{l}\text { C. G., M.H. } \\
\text { C. G., M. H. } \\
\text { Polycystic disease } \\
\text { C. G. single R. kidney } \\
\text { C.P. } \\
\text { C. G. } \\
\text { C. G., M. H. }\end{array}$ & $\begin{array}{l}400 \\
350 \\
306 \\
530 \\
480 \\
276 \\
275\end{array}$ & $\begin{array}{l}20 \\
19 \cdot 2 \\
14.6 \\
14.6 \\
16.4 \\
18.4 \\
15 \cdot 6\end{array}$ & $\begin{array}{l}\text { Anuric } \\
1 \\
8 \\
4 \\
3 \\
1 \cdot 25 \\
1\end{array}$ \\
\hline
\end{tabular}
C. G. $=$ Chronic glomerulonephritis. M. H. = Malignant hypertension. C. P.e-
Chronic pyelonephritis. P. Cr. $=$ Plasma creatininc. Cr. Cl. = Creatinine clearance.

Haemodialysis.-The plasma colistin sulphomethate sodium levels in the four patients given the drug in between haemodialyses are shown in Table II. The results of the plasma colistin levels in the three patients given the drug at the beginning of a haemodialysis are shown in Table III. The rate of fall of plasma colistin levels was calculated from the highest observed level and expressed as $\mu \mathrm{g} . / \mathrm{ml}$./hour. The results are shown

TABLB II.-Colistin Levels in Patients Not Being Dialysed

\begin{tabular}{|c|c|c|c|c|c|c|c|c|}
\hline \multirow{2}{*}{$\begin{array}{l}\text { Case } \\
\text { No. }\end{array}$} & \multirow{2}{*}{ Weight } & \multirow{2}{*}{ Dose } & \multicolumn{6}{|c|}{ Plasma Colistin levels ( $\mu \mathrm{g} . / \mathrm{ml}$. ) } \\
\hline & & & Control & $10 \mathrm{Min}$. & $2-3 \mathrm{hr}$. & $24 \mathrm{hr}$. & $48 \mathrm{hr}$. & $56 \mathrm{hr}$. \\
\hline $\begin{array}{l}3 \\
4 \\
6 \\
7\end{array}$ & $\begin{array}{l}60 \mathrm{~kg} . \\
40 \mathrm{~kg} . \\
80 \mathrm{~kg} . \\
41 \mathrm{~kg} .\end{array}$ & $\begin{array}{c}3 \mathrm{mg} . / \mathrm{kg} . \\
" \\
, \\
,\end{array}$ & $\begin{array}{l}7 \cdot 8 \\
0 \\
1 \cdot 26 \\
0\end{array}$ & \begin{tabular}{|l}
34.0 \\
11.4 \\
32.0 \\
13.6
\end{tabular} & $\begin{array}{r}29 \cdot 0 \\
13.0 \\
22.5 \\
9.8\end{array}$ & $\begin{array}{r}21.5 \\
5.9 \\
19.4 \\
4.6\end{array}$ & $\begin{array}{l}9 \cdot 2 \\
0 \cdot 74 \\
=\end{array}$ & $\begin{array}{l}\overline{7} \\
5.0 \\
1.84\end{array}$ \\
\hline
\end{tabular}

TABLE III.-Colistin Levels During Haemodialysis

\begin{tabular}{|c|c|c|c|c|c|}
\hline \multirow{2}{*}{$\begin{array}{l}\text { Case } \\
\text { No. }\end{array}$} & \multirow[b]{2}{*}{ Dose } & \multicolumn{4}{|c|}{ Plasma Colistin Levels $(\mu \mathrm{g} / \mathrm{ml}$.). } \\
\hline & & $\begin{array}{c}\text { Control } \\
\text { (Pre-dialysis) }\end{array}$ & $10 \mathrm{Min}$. & $2 \mathrm{Hr}$. & Post-dialysis \\
\hline $\begin{array}{l}3 \\
6 \\
7\end{array}$ & $\begin{array}{c}3 \text { mg./kg. } \\
" \\
"\end{array}$ & $\begin{array}{l}1 \cdot 0 \\
5 \cdot 0 \\
0 \cdot 1\end{array}$ & $\begin{array}{l}36 \cdot 0 \\
23 \cdot 0 \\
16 \cdot 0\end{array}$ & $\begin{array}{c}15 \cdot 4 \\
19 \cdot 4 \\
-\end{array}$ & $\begin{array}{r}14.0(11.2 \mathrm{hr} .) \\
13.2(12.5 \mathrm{hr} .) \\
4.7(16 \mathrm{hr} .) .\end{array}$ \\
\hline
\end{tabular}


in Table IV. The mean rate of fall in plasma level without haemodialysis was $0.36 \mu \mathrm{g} . / \mathrm{ml}$./hour (S.D. \pm 0.13 ) and the mean rate of fall during haemodialysis was $1.16 \mu \mathrm{g} . / \mathrm{ml}$./hour (S.D. \pm 0.59 ). The difference between the means is probably significant $(t=2.28 ; \mathrm{P}<0.1)$. The disappearance rate of colistin is therefore increased by haemodialysis, using the Kiil type of dialyser with cuprophane membrane PT150.

\begin{tabular}{c|c|c}
\multicolumn{2}{c}{ TABLB IV.-Rate in Fall of Plasma Colistin Levels ( $\mathrm{\mu g} . / \mathrm{ml} . /$ hour) } \\
\hline Case No. & Without Haemodialysis & During Haemodialysis \\
\hline 3 & 0.52 & 2.0 \\
4 & 0.26 & 0.78 \\
6 & 0.47 & 0.71 \\
7 & 0.21 & 0.78
\end{tabular}

Peritoneal Dialysis.-Peritoneal clearances of colistin sulphomethate sodium were measured over two consecutive exchanges in each patient. The concentrations of colistin in the peritoneal dialysis fluid, together with the corresponding clearances, are shown in Table V. The mean peritoneal dialysate colistin concentration was $4.7 \mu \mathrm{g} . / \mathrm{ml}$. and the mean peritoneal clearance was $9.8 \mathrm{ml} . / \mathrm{min}$. The plasma levels of colistin were followed long enough in two of these patients for a calculation of the disappearance rate to be made. The esults of the plasma levels are shown in Table VI. The disappearance rate in these two patients was 0.26 and 0.36 $\mu \mathrm{g} . / \mathrm{ml}$./hour respectively, which falls within the same range as that of the four patients given colistin when they were not being dialysed. It is concluded that removal of colistin by peritoneal dialysis is poor and does not alter the rate of disappearance of colistin from the blood.

\begin{tabular}{|c|c|c|c|c|}
\hline $\begin{array}{l}\text { Case } \\
\text { No. }\end{array}$ & Weight & Dose & $\begin{array}{l}\text { Peritoneal } \\
\text { Colistin Conc. }(\mu \mathrm{g} . / \mathrm{ml} .)\end{array}$ & $\begin{array}{c}\text { Peritoneal } \\
\text { Clearance (ml./min.) }\end{array}$ \\
\hline 1 & $51 \mathrm{~kg}$. & $2 \mathrm{mg} . / \mathrm{kg}$. & $\left\{\begin{array}{l}7 \cdot 0 \\
7 \cdot 2\end{array}\right.$ & $\begin{array}{l}15.8 \\
11.9\end{array}$ \\
\hline 2 & $60 \mathrm{~kg}$. & $2 \mathrm{mg} . / \mathrm{kg}$. & $\left\{\begin{array}{l}5.9 \\
5.6\end{array}\right.$ & $\begin{array}{r}9 \cdot 6 \\
13 \cdot 0\end{array}$ \\
\hline 5 & $50 \mathrm{~kg}$. & $3 \mathrm{mg} . / \mathrm{kg}$. & $\left\{\begin{array}{l}2.05 \\
0.76\end{array}\right.$ & $\begin{array}{l}6 \\
2 \cdot 8\end{array}$ \\
\hline
\end{tabular}

\begin{tabular}{|c|c|c|c|c|c|c|c|}
\hline \multirow{2}{*}{$\begin{array}{l}\text { Case } \\
\text { No. }\end{array}$} & \multirow{2}{*}{$\mathbf{W t}$} & \multirow{2}{*}{ Dose } & \multicolumn{5}{|c|}{ Plasma Colistin levels ( $\mu \mathrm{g} . / \mathrm{ml})}$. \\
\hline & & & Control & $10 \mathrm{~min}$. & $2 \mathrm{hr}$. & $24 \mathrm{hr}$. & $48 \mathrm{hr}$. \\
\hline$\frac{1}{5}$ & $\begin{array}{l}51 \mathrm{~kg} . \\
50 \mathrm{~kg} .\end{array}$ & $\begin{array}{l}2 \mathrm{mg} / / \mathrm{kg} . \\
3 \mathrm{mg} . / \mathrm{kg} .\end{array}$ & $\begin{array}{l}1.52 \\
0.1\end{array}$ & $\overline{10 \cdot 0}$ & $\begin{array}{r}15 \cdot 8 \\
7.8\end{array}$ & $\underset{11.46}{11.4}$ & $0 . \overline{73}$ \\
\hline
\end{tabular}

Side-effects.-Two patients (Cases 6 and 7), both of whom received $3 \mathrm{mg}$.. of colistin sulphomethate sodium per $\mathrm{kg}$. body weight intravenously, complained spontaneously of mild giddiness and unsteadiness of gait for 24 to 48 hours after one dose. No other side-effects were noted during this study.

\section{Discussion}

There are conflicting reports on the dialysability of colistin sulphomethate sodium. MacKay and Kaye (1964) confirmed that prolonged elevation of colistin blood levels occurred in the presence of severe renal failure. Using a Kolff twin-coil type of dialyser, they failed to demonstrate any change in serum levels of colistin during haemodialysis. However, Gombos, Katz, Fedorko, Allnoch, and Lee (1964), using a Kiil type of dialyser, produced evidence of reduction in serum colistin levels during haemodialysis. They suggested that the serial tube dilution assay method employed by MacKay and Kaye (1964) was less sensitive than the plate method they employed, and that this accounted for the difference in their results.
Greenberg and Sanford (1967) studied the effect of peritoneal dialysis on colistin blood levels in three patients with severe renal failure and showed that removal of colistin was poor, with an average peritoneal clearance of $11.3 \mathrm{ml} . / \mathrm{min}$.

The present study confirms the observations of Gombos et al. (1964) that haemodialysis with the Kiil type of dialyser results in a fall in blood levels of colistin. Though it is not clear what type of membrane was employed by Gombos et al. (1964) in the Kiil type of dialyser, another explanation for the difference between their results and those of MacKay and Kaye (1964) is that the membrane used by Gombos et al. was thinner and more permeable to colistin than the cellophane usually employed in the Kolff twin-coil type of dialyser. In the present study cuprophane PT150 was used in the Kiil dialyser.

The present study also confirms the observations of Greenberg and Sanford (1967) with regard to the peritoneal clearance of colistin. The average peritoneal clearance of colistin found by these workers was $11.3 \mathrm{ml} . / \mathrm{min}$., while in the present study the average clearance was $9.8 \mathrm{ml} . / \mathrm{min}$.

Our results show that in patients with severe renal failure who are not being dialysed significant levels of colistin may still be present in the blood two to three days after a single dose of $2-3 \mathrm{mg}$. $/ \mathrm{kg}$. body weight intravenously. When blood levels of colistin are not easily obtainable a suitable dosage schedule for patients with severe renal failure is $2-3 \mathrm{mg} . / \mathrm{kg}$. body weight intravenously every three days. Peritoneal clearance of colistin is small and the same schedule is suggested when this technique is used. In patients undergoing twice-weekly haemodialysis, and where the Kiil type of dialyser with cuprophane membrane PT150 is used, a dose of 2-3 mg. $/ \mathrm{kg}$. body weight intravenously at the end of each dialysis is suggested. It is particularly convenient in patients on intermittent haemodialysis to be able to give colistin sulphomethate sodium intravenously in a small volume, since these patients are heparinized during dialysis and many are on long-term anticoagulant therapy.

\section{Summary}

Prolonged elevation of plasma levels of colistin sulphomethate sodium in patients with severe renal failure is confirmed.

Haemodialysis with the Kiil type of dialyser and cuprophane membrane PT150, produces an increase in the rate of disappearance of the colistin.

In patients undergoing twice-weekly haemodialysis with this type of dialyser, a dosage schedule of $2-3 \mathrm{mg}$. $/ \mathrm{kg}$. body weight intravenously at the end of each dialysis is suggested.

In patients with severe renal failure and endogenous creatinine clearances of $<10 \mathrm{ml}$./min. a dose schedule of $2-3 \mathrm{mg} . / \mathrm{kg}$. body weight intravenously every three days is suggested. Peritoneal clearance of colistin is poor and no further modification of this dose schedule is recommended when peritoneal dialysis is employed.

We wish to thank Sister J. M. Storey and the staff of the renal unit, Fulham Hospital, who collected some of the blood samples. The colistin sulphomethate sodium assays were carried out by Dr. B. N. Kliger, of Pharmax-Laboratories.

\section{REFERENCES}

Colley, E. W., and Frankel, H. L. (1963). Brit. med. 7., 2, 790

Gombos, E. A., Katz, S., Fedorko, J., Allnoch, H., and Lee, T. H. (1964). Antimicrobial Agents and Chemotherapy, p. 373.

Greenberg, P. A., and Sanford, J. P. (1967). Ann. intern. Med., 66, 465. Mackay, D. N., and Kaye, D. (1964). New Engl. f. Med., 270, 394. McMillan, M., Price, T. M. L., MacLaren, D. M., and Scot,, G. W. (1962). Lancet, 2, 737. 